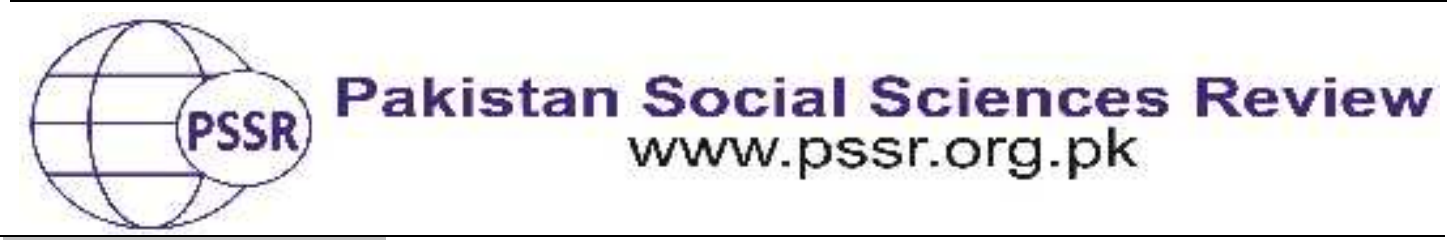

RESEARCH PAPER

\title{
Securing Tomorrow: An Operational Risk Capital Cushion Perspective
}

\author{
Muhammad Zohair Durrani ${ }^{* 1}$ Dr. Umar Safdar Kayani ${ }^{2}$ Inamullah Khan ${ }^{3}$
}

1. Ph. D Scholar, School of Business Administration, NCBA\&E, Lahore, Punjab, Pakistan

2. Associate Professor, HOD, School of Business Administration, NCBA\&E, Lahore, Punjab, Pakistan

3. Ph. D Scholar, School of Business Administration, NCBA\&E, Lahore, Punjab, Pakistan

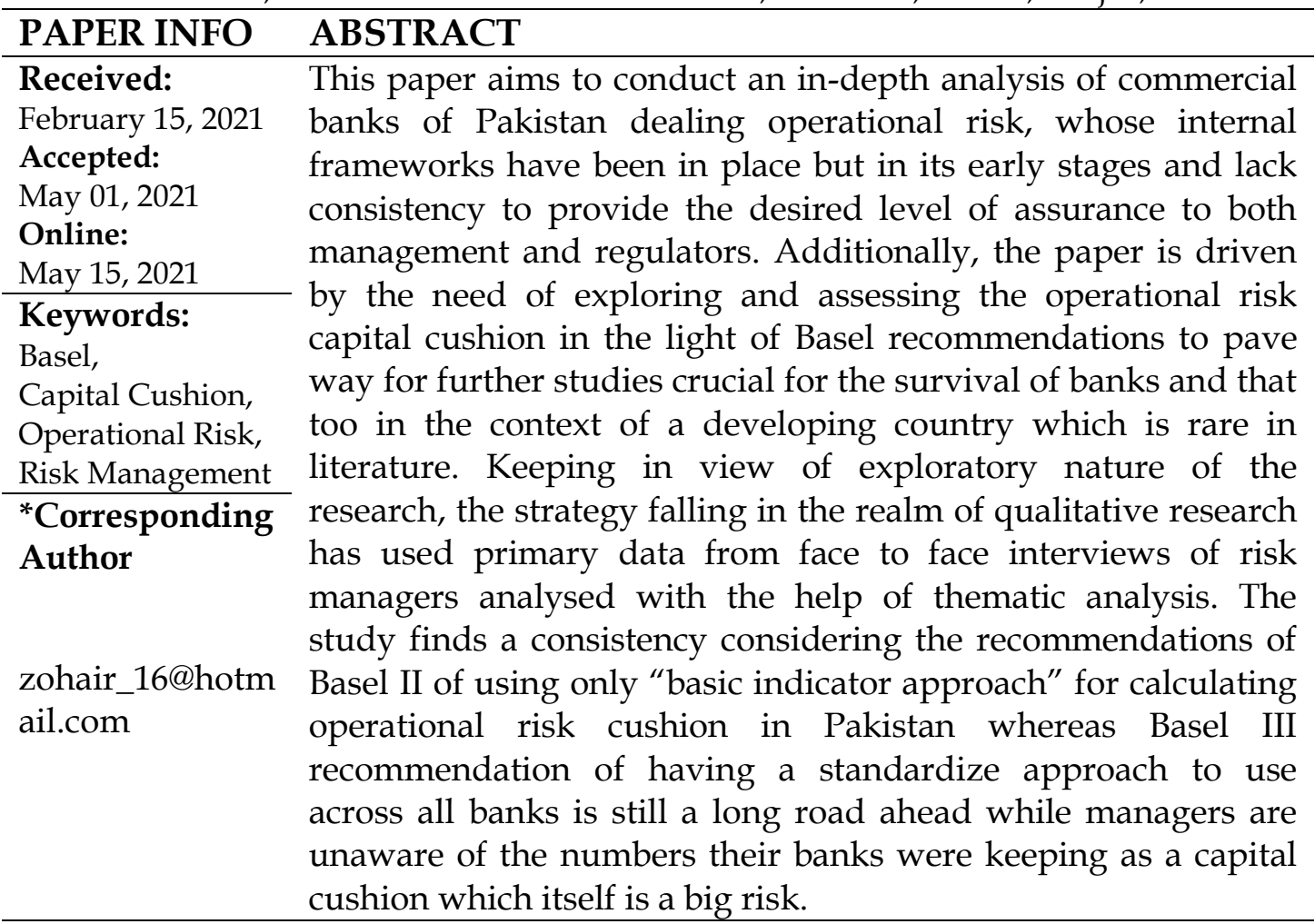

\section{Introduction}

In its business activities, the bank and its executives are constantly and inevitably facing an increasing number of risks, the most common of which are credit, liquidity, market and operational risks (Kozarević, et. al. 2013). Over the past decade, regulators and managers have paid astronomical attention to operational risk, which has been identified as an increasingly important factor in bank performance and stability (Abdymomunov, et. al. ,2017), which previously considered as residual risk (Jarrow\& Turnbull, 2000; Power 2005). Many banks define operational risk as "any risk that is not classified as market or credit risk (Hopkin, 2018), while a positive definition of the expression that describes what 
operational risk is defined by the Basel Committee in 2001 which refers operational risk as the risk of loss arising from inadequate or failed internal processes, people and systems or from external events. This definition includes legal risk but excludes strategic and reputational risk (BIS, 2011).The existence of operational risk, though present yet un-interpreted before, got highlighted after the collapses of barring bank in 1995, Allied Irish bank and the fraudulent trading's at UBS (Gillet, et. al. 2013; Jiang, 2018) which resulted in active risk management (Kozarević et al., 2013). The growing size of financial institutions dealing in money with respect to their size, organizational complexities, their new products along with advancement in technology and fierce competition within the market has increased the chance of occurrence of operational losses.

According to Abdymomunov et al., (2017) financial institutions with a weak risk management procedure experience higher and more volatile operational losses whereas effective operational risk management is necessary for the success and existence of the bank, either Islamic or conventional, and its importance is increasing over time, particularly after the recent crises and the recession (Rehman, Benamraoui, \& Dad, 2018). The associated losses related to this risk i:e operational risk range from rogue traders, fraud, settlement failure, poor accounting, miss selling and lapses in financial control. To offset this, a bank with a significant operating loss can withhold loans or other activities to create the capacity to absorb the loss and ensure survival (Sands, P., Liao, G., \& Ma, Y, 2018) and make the banks more sustainable and bearable to unforeseen shocks.

In order to build the capacity to absorb such losses, banks need to have adequate capital, reserve requirements or retained capacity as a buffer i:e banks need to hedge for any unexpected losses or risk they ought to face and therefore supported by agency theory that managers can go for hedging without considering the shareholders interest (Tufano, 1998). It is however, highlighted that adoption of single theory is not enough to explain the rationale for risk management (Hudin\& Hamid, 2014)) hence this study also takes into consideration of Modigliai-miller theorem (Dan, et. al. 2005). Moreover, one of the key indicators in assessing the integrity of banking operations is the capital adequacy. The idea for holding a buffer for operational risk is more recent i:e. 2004, when Basel 2 first introduced the requirement (Muljawan, et. al. 2004; Sands et al, 2018).

These banks or financial institutions are the core of every economy and their survival under adverse economic conditions are related to the methods of their computation of capital adequacy and the way they manage their risks (Sharifi, Haldar\& Rao, 2016). A poor and deficient banking system can have a serious impact on overall economic performance, which can lead to a widespread financial crisis. Many researchers believe that the bankruptcy of many financial institutions during the crisis is associated with an inadequate risk management practices (Aebi, et. al. 2012; Rehman et al., 2018). It is therefore, vital for banks that operate complex businesses to establish efficient risk management processes in order to avoid heavy losses (Rehman et. al., 2018). Additionally, the Basel Committee on Banking Supervision (BCBS) has proposed a reform of risk-weighted assets, replacing the 
current system that gives banks a choice between three methods of different complexity and reliance on internal models, with an approach called standardized measurement approach (Sands et. al., 2018). These mandatory requirements are designed to improve and augment the ability of individual banks to absorb temporary financial shocks (Muljawan et al., 2004). According to Lessanbo (2020) Basel II prescribes various approaches to calculate capital cushion for operational risk that banks and similar financial institutions have (i) basic indicator approach, (ii) standardized approach, and (iii) advanced measurement approaches but on March 4, 2016, the Basel Committee on Banking Supervision finally updated its proposal for calculating operational risk capital, introducing the Standardized Measurement Approach ("SMA"). Building upon its 2014 version, the SMA would not only replace the existing standardized approaches, but also the Advanced Measurement Approach. Under the SMA, regulatory capital levels will be determined using a simple formulaic method which facilitates comparability across the industry. Furthermore, the scarce literature in particular to calculating operational risk in a developing country like Pakistan, where international standards are being implemented but seems to be in its inception, prompts and urge the need to explore the area further and it would be interesting to examine the operational risk capital adequacy implementation level within the Pakistani setting and how commercial banks operating in Pakistan are in pace with the rest of the world.

According to Anwer (2013), a representative from the Central Bank of Pakistan agrees that although Pakistan has established internal and informal operational risk management frameworks, these frameworks are not documented, inconsistent and do not provide the required level of confidence, both management and regulators. Moreover, Operational risk capital requirements represent a relative backwater of the Basel capital framework for banks (Sands et al., 2018) and is important to assess the changes introduced by banks itself to handle activities that are prone to operational risk and its capital adequacy. It is therefore, a dire need to investigate whether commercial banks operating in Pakistan are implementing international standards when it comes to a bank's capital need. The purpose of this research is to investigate operational risk management in general while Operational risk's capital cushion in particular. In doing so, the investigation of capital adequacy for operational risk can pave way for future studies related to its framework i:e operational risk management framework. This will not only be providing an overview for the bank managers, investors, regulators and policymakers as it will serve them as guide when developing, reformulating and overseeing the bank's existing risk management practices in particular to operational risk, but will also add a new perspective to the existing research on operational risk management of banks in Pakistan. The study area is crucial for regulators, monitoring authorities and critical to the survival of banks since it is evident that one cannot explore, describe, explain or predict a solution to a problem until it is clearly understood in our case, investigating whether commercial banks operating in Pakistan are in line with Basel requirements of capital adequacy or not. 


\section{Literature Review}

This section reviews the existing literature to excavate the context and a thorough understanding of operational risk and its capital adequacy within and outside of Pakistan. Operational risk has proven to be an important aspect of the risk management policy / program of all financial institutions. According to Hopkin (2018), the term operational risk has several meanings and some financial institutions use different terms or broader definitions. He also pointed out that initial operational risk was defined as a risk that was not market or credit risk, but was replaced by the Basel II definition: "the risk of loss due to inadequate or failed internal processes, people and systems, or external events. Operational risk is not considered a market credit risk, but Basel II has been replaced by Basel II that is, "Risk of loss due to insufficient or failed internal processes, people and systems or external events". Operational risk is regarded as something other than credit and market risk.

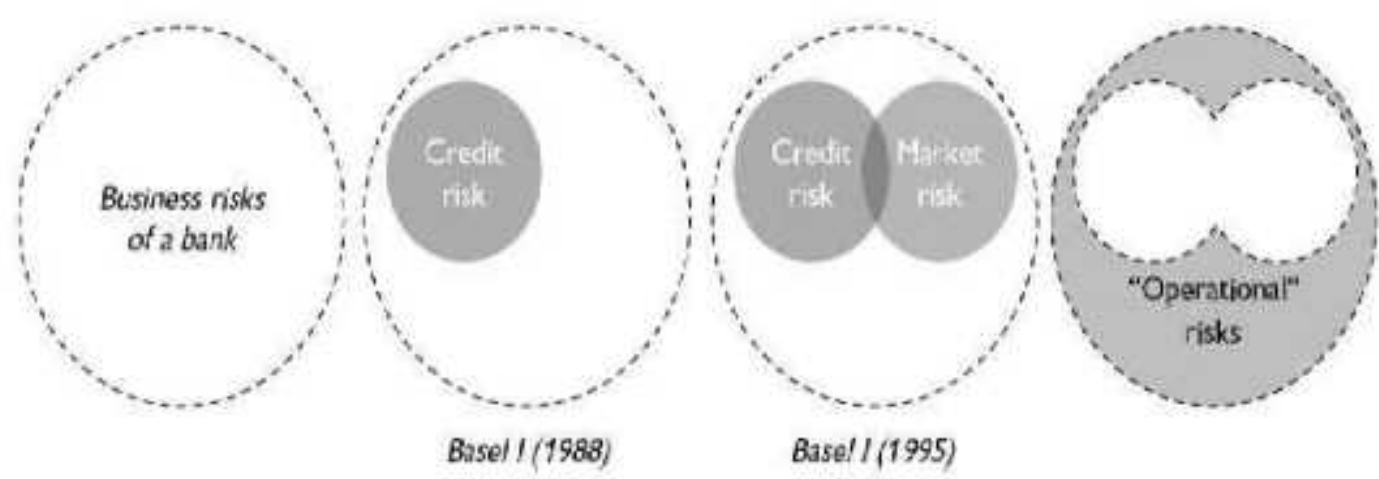

Figure 01 Operational Risk Evaluation

Due to the potential for large losses, regulators have pushed the banking industry to better measure and manage operational risk (Chernobai et al., 2018)whereas the focus on operational risk management has increased significantly in recent years(Wei, et. al. 2006). Banks must have sufficient capital to operate in the risky world in which they operate and each bank has an obligation to maintain and maintain a capital buffer for any exposure to risk or shock that may arise during the operation. Banks need to categorize and quantify these risks according to their capital (Ferretti, 2018).

The Basel I standards were established in 1988 to acquaint with minimum capital requirements for banks which was accepted by over 100 countries and its general acceptance was by most banks globally (Engelen, 2005; Masood \& Fry, 2012). However, over time, the agreement has improved given the financial innovations and some risks that have not been addressed before (Santos, 2001) and thus considering the Basel II regulatory framework, which is a more comprehensive and sensitive approach. at risk of capital adjustment adopted in 2004 to reform Basel 1, implementation started in 2006, resulting in a three-pillar approach:) market 
discipline (Zins \& Weill, 2017; Zeuli \& Carvalhal, 2018; Gurrea \& Remolina, 2019). In the years after the international financial crisis of subprime mortgages of 2007, the need to rethink prudential rules to warrant greater stability, resilience and transparency in the banking system led to the signing of Basel III (Ferretti, 2018), which many believe it is an amendment of Basel II (Zeuli \&Carvalhall,2018). Basel III has made significant progress in financial regulation since the onset of the global financial crisis, which marks a milestone in a new difficult global economic situation (Caruana, 2010). Basel III has indicated the weaker points in the definition of capital and has made additions in terms of introduction of liquidity risk management (Docherty \&Viort, 2013, p.142). Unlike Basel II, Basel III has proposed changes to the definition of the capital introduced in Basel I. Basel III is introduced to ensure that the banks should have more financial resources and capital to operate in normal and stress condition in order to have the capacity to absorb shocks arising from the financial and economic stress, so that the effect of risks does not impact on the real economy (Basel Committee on Banking Supervision, 2011).

The Basel Accords were originally developed primarily for the G10 countries. However, these guidelines are designed to be applicable in both developed and developing countries (Al-Tamimi, 2008). Van, et. al. (2004) said that, the enactment of the Basel Accords can have an optimistic impact on risk management and improve financial sustainability by providing a risk-sensitive methodology. Masood and Fry (2012) also also suggest that successful implementation of the Basel Accord is clearly an important factor in facilitating the survival and prosperity of banking institutions in risky environment.

A study by Tanna (2016) analyzed the pros and cons of implementing Basel III in Indian banks and concluded that Basel III brings various benefits to Indian banks, such as better portfolio and risk management, Effective supervision, greater operational transparency, increased risk sensitivity and balanced returns, however banks tend to face more challenges in the implementation process, such as higher capital maintenance costs and difficulties in raising funds for small banks.In addition, as part of the new Basel capital adequacy framework, the Basel capital charge is a step towards managing operational risk ( $\mathrm{Xu}$, et. al. 2017), which further believes that it is difficult to signify operational risk and its various forms. King and Tarbet (2011) also agreed with the above statement, arguing that the crisis showed illumination and erosion of capital levels, leaving banks in a state of austerity to compensate for losses. Subsequently, the lack of capital and poor quality proposed by Basel II triggered a crisis. According to Aatira and Shanti (2013), Basel III represents a positive outlook because it increases capital requirements and ensures consistency in liquidity standards. However, Slovik (2012) believes that the impact of Basel III is short-lived. This shows that there are various controversies regarding the application of Basel III, especially in terms of operational risk management. 
Narrowing down further, the literature regarding operational risk management pertinent to Pakistan, an emerging economy, is scares and in proximity to none. Very few studies were available such as (Habib, et. al. 2014) examined the current status of operational risk management in banking sector of Pakistan. Their research focused on the reasons for adopting or not adopting an integrated approach to manage operational risk and found that effective risk management can improve the performance of an organization, but an adequate infrastructure is a pre-requisite. They further stated that the concept of operational risk management can be seen to some extend in banking sector. Another study by Khan (2015) highlighted the conditions under which operational risk management plays a vital role in the development and strengthening of financial institution, by identifying the impact of operational risk management on financial institutions in developed and developing countries. The study further found that operational risk management is not considered crucial or important part of the risk management process and is overlooked by the developing countries. Khan and khan (2018) investigated the impact of ownership structure and firm size on the operational risk management (ORM) in the context of Islamic banks in Pakistan. They used Basic Indicator Approach (BIA), and Standardize Approach (STA) to measure the minimum capital required for managing operational risk for 19 Islamic banks which were listed on the Pakistan Stock Exchange and found that an increase in the size of the Islamic banks tend to lower the surplus capital maintain by banks for managing operational risk whereas a significant positive relationship between excess capitals required for managing operational risk and public owned Islamic banks.

\section{Material and Methods}

This research starts with a detailed literature review to understand the study background of the research topic and is based on the contextual understanding, which adopts an inductive research approach to answer research questions by employing qualitative research strategy. Primary data sources were used to reach the answers to research question by face to face interviews conducted by the researcher with the risk management personnel's primarily working in the operational risk management department of the chosen commercial bank because of their involvement in risk management process ranging from its identification, estimation, evaluation and monitoring activities. The meetings started with a concise introduction of the topic under investigation and members were guaranteed about information confidentiality and personal secrecy. In order to maintain reliability and validity of the data, the interviews were recorded after seeking prior consent of the participants and were transcribed and sent for member checking (Cohen, et. al. 2017).

In addition, participants were given a demographic survey to complete as a source of background information at the end of each interview. Once the data was taken in the raw form the next step was to interpret it and therefore, thematic analysiswas undertaken to identify and organize the data for qualitative analysis and the emerging themes arising from it (Stirling \&Attride, 2001; Nowell,L. S., Norris, J. M., White, D. E., \& Moules, N. J., 2017).The interpretation of qualitative 
data is a challenging phase of this research and considering the novelty of operational risk management in Pakistan banks, all data gathered through interviews was considered relevant. This method, thematic analysis, is the most widely used qualitative approach in analysing interviews by identifying, analysing and reporting patterns (themes) within the data to produce an insightful analysis that answers particular research questions (Braun \& Clarke, 2006). This research used NVIVO software to manage the data from the interview because it provides a structured approach to store data in one place in an effective and efficient manner. Such invaluable software will help to examine relationships between the themes as endorsed by King (2004, p. 263).

The study population of this study is the commercial banks of Pakistan listed at the state bank's website. Table 1 shows the population of the study i: e 21 commercial banks in total operating in Pakistan, although commercial banks operating in Pakistan differ in size and business orientation, they are homogenous and discrete groups, working under the supervision of the same regulator that is SBP, who are required to maintain strict operating standards in their business activities including risk management. The commercial banks of Pakistan represent a homogeneous and discrete group although they may differ in terms of size and business focus. They are all, however, regulated by the same body, the SBP and will, therefore, be required to maintain sound standards of operation in their business activities, including risk management.

Table 1

\begin{tabular}{cccc}
\hline Sr. & Population Banks & Sr. & Population Banks \\
\hline 1 & Askari Bank & 12 & Habib Bank Limited \\
\hline 2 & Bank of Punjab & 13 & Standard Chartered Bank \\
\hline 3 & Faysal Bank & 14 & Bank Al-Habib \\
\hline 4 & Habib Metropolitan Bank & 15 & Bank of Khyber \\
\hline 5 & Muslim Commercial Bank & 16 & Sindh Bank \\
\hline 6 & National Bank Pakistan & 17 & Samba Bank \\
\hline 7 & Silk Bank & 18 & Citi Bank \\
\hline 8 & Soneri Bank & 19 & Bank of China \\
\hline 9 & United Bank Limited & 20 & JS Bank \\
\hline 10 & Allied Bank Limited & 21 & Summit Bank \\
\hline 11 & Alfalah Bank & &
\end{tabular}

The study chooses commercial bank for a number of reasons. Firstly, the financial crisis of 2008 has highlighted the need to understand the operational risks and therefore this study can be helpful in the subject concerning commercial banks. Secondly, there is a growing pressure from the regulator of Pakistan i:e the State bank, to ensure adequate and transparent risk management frameworks to counteract operational risk exposures which are still lacking consistency and do not provide the desired level of assurance to both management and regulator (Anwer, 2013). Thirdly, there is also a pressure at the commercial bank's part to ensure that it 
establishes or maintains adequate risk management frameworks and internal controls to counteract operational risk exposures.

The sample consists of employees of banks selected on the basis of the level of assets held by these banks. It is important that these institutions are the most influential institutions: they will implement operational risk management (ORM) technology in accordance with Basel requirements and will be able to adopt practices considered best practices or operational risk management practices.

Table 2 illustrates the sample bank along with the total assets they hold and the liabilities they have as on 30th December, 2019.

Table 2

\begin{tabular}{cccc}
\hline Sr. & Sample Banks & $\begin{array}{c}\text { Total Assets } \\
\text { (In millions) }\end{array}$ & $\begin{array}{c}\text { Total Liabilities } \\
\text { (In millions) }\end{array}$ \\
\hline 1 & Askari Bank & 833,443 & 791,041 \\
\hline 2 & Bank of Punjab & 869,682 & 822,815 \\
\hline 3 & Faysal Bank & 629,861 & 574,656 \\
\hline 4 & Habib Metropolitan Bank & 865,030 & 817,200 \\
\hline 5 & Muslim Commercial Bank & $1,612,215$ & $1,440,868$ \\
\hline 6 & National Bank Pakistan & $3,132,360$ & $2,893,137$ \\
\hline 7 & Silk Bank & 205,688 & 194,916 \\
\hline 8 & Soneri Bank & 442,541 & 422,327 \\
\hline 9 & United Bank Limited & $2,023,738$ & $1,832,866$ \\
\hline 10 & Allied Bank Limited & $1,483,383$ & $1,366,171$ \\
\hline 11 & Alfalah Bank & $1,067,110$ & 977,827 \\
\hline 12 & Habib Bank Limited & $3,227,132$ & $3,002,380$ \\
\hline 13 & Standard Chartered Bank & 619,971 & 547,054 \\
\hline 14 & Bank Al-Habib & $1,299,139$ & $1,237,206$ \\
\hline \multicolumn{4}{c}{ Source (Banking results 2019, Taseerhadi) }
\end{tabular}

The research interviewed 14 participants out of 21 in Pakistan commercial banks from December 2019 to February 2020 but were further prolonged till April 2020 due to the unavailability of the participants owing to the outbreak of corona virus. The minimum number of interviews needs to be in between the given number i.e. twenty and thirty proposed by Warren's (2002) for an interview-based qualitative report to be published (Bryman, 2012,p. 425). The presence of, approximately, 21 commercial banks in Pakistan makes the 14-interview sample robust and adequate. The interviewees were chosen based on the non-probability judgement basis, which enables data to be gathered from interviewees encapsulating a wide range of experience and characteristics (Marshal, 1996). In this regard, every effort was made to choose the participants in relation to their exposure to, and experience in, operational risk management and governance. More than one risk manager from same bank was interviewed. 


\section{Results and Discussion}

All the interviews were conducted in a friendly, cooperative manner while the interviewees were willing and helpful to participate in the research. Eleven of the respondents were male and two females; the respondent's age were in the range of 28 to 48 years, (1) between 25 - 30 and (5) were between 30 - 35 and (7) were above 35 years of age. Of the 13 respondents, all held Master while 2 obtained extra degree i:e CFA and ACCA degree. The work experience varied from 3 years to 15 years. 4 respondents were in 3 to 5 years range while 9 respondents were in 10 to 15 years range. Although the interviewees set aside time for the interview appointment, some interruptions did occur in some interviews and are recorded which are minor deviations. All interviews were however completed in full.

The interviews began by seeking a general understanding of respondents and based on the responses about their knowledge regarding operational risk, its definition and categorization of operational loss event, the researcher tried to seek responses regarding what sufficient capital reserves are required by the banks to keep in case of any actual or potential financial losses or obligations faced or yet to be faced by the bank? This is a key requirement of the regulatory framework set out for banks in the Basel II Accord (Hopkin, 2018). The responses reveal that most of the respondents either felt reluctant or were unaware of the numbers their banks were keeping for the total risk. For example,

Respondent (A) stated:

"I think this is a tricky one, due to the sensitivity of its nature, confidential information, we are doing what the regulator has set for us".

Similarly, respondent $(\mathrm{K})$ said:

"Can't share this information" whereas respondent (L) felt shy while stating that "I do not have any idea regarding the total risk percentage".

The interview responses display little clarity and lack of knowledge regarding the capital requirements at the respondents end while a firm understanding is missing. In a similar tone respondent $(\mathrm{E})$ stated:

"Actually, at this moment I don't have any idea. There is a limit but that is not clear in my mind right now".

Out of total 14 respondents only 3 respondents actually knew how much total risk is kept by their bank and what the regulator had set the bench mark for them and amongst these three respondents only one respondent knew the exact knowledge and the numbers when respondent (J) stated: 
"CAR which is currently set at $10.25 \%$ and will be gradually increased to $12.5 \%$ by December 31, 2019 as per Basel III instructions".

Such response, alarmingly, highlight that risk management personnel's working within commercial banks are not too much familiar and lack awareness which in itself is a risk because they are the ones managing risks for the bank and their effectiveness seems compromised. This is also supported by Hemrit\& Arab (2012) that "It turns out that operational risk arises from lack of awareness and deficiencies of skill in detecting threats related to this risk".

Furthermore, the study then focused on enquiring and getting replies regarding whether the banks had kept capital cushion for its operational risk and whether these were being calculated according to Basel 2 recommendation or Basel 3 and found surprisingly that out of total of 14 respondents only one respondent i:e respondent (B) answered that:

"this limit has also been defined and we kept it at $8 \%$ of our operations...." whereas the remaining 13 respondents were not sure and replied in consistently "can't tell, not sure, or its confidential".

The interview narrowed down further to its research questions regarding operational risk cushion and Basel recommendations and found that at the respondents end i:e out of 14 respondents, mostly were of the view that the recommendation of Basel 2 of using Basic Indicator approach is being used by their bank to calculate its operational risk cushion while two of the respondents, one bank representative stated that they were using SMA i:e standard measurement approach while another respondent stated that they were using AMA i:e Advanced measurement approach as stated in Basel 2 accord. It is therefore concluded that the banks are mainly using basic indicator approach as given in Basel 2 while the approach recommended in Basel 3 is yet to be implemented.

Respondent (G) states that:

"mainly basic indicator approach is used but there are other approaches but I don't think banks have migrated on those yet because these are the latest approach being implemented in operational risk guidelines since 2015 when prudential regulation came on it hence it is still not matured in banks risk management department"

In a similar tone respondent $(\mathrm{A})$ opinions that:

"Currently using basic indicator approach but we need to further enhance and get ourselves to gear up for the new approach as given by the Basel 3 but it won't be until next year".

The study finds that commercial banks operating in Pakistan have been in toe with Basel 2 recommendations but implementing Basel 3 recommendations of having a Standardize approach across all banks to calculate operational risk is still a long journey. 


\section{Conclusion}

This research paper is an endeavour towards outlining the significance of capital adequacy stemming out of agency theory for commercial banks in the light of Basel accord with special reference to a developing economy like Pakistan. Capital adequacy plays a pivotal role for the survival of the banks in particular and for the economy in general. The study is unique in its right on account of being an explorative one with key outcomes pertaining to capital adequacy understanding amongst the risk management personnel of 14 commercial banks. To the surprise of the researcher, the responses revealed that most of the respondents felt reluctant and were unaware of the numbers their banks were keeping as a capital cushion, whereas only 3 respondents actually knew how much capital cushion is kept for total risk by their bank and what benchmark is set by the regulator i:e SBP. On further enquiry it was found that out of 14 respondents in total, only 1 respondent knew about the capital cushion kept for operational risk and whether this was being calculated according to Basel 2 recommendation or Basel 3. Such response, alarmingly, highlight that risk management personnel's working within commercial banks are not too much familiar and lack awareness which in itself is a risk (Hemrit\& Arab, 2012)because they are the ones managing risks for the bank and their effectiveness seems compromised. In addition, even after the advent of Basel III, some people proposed to replace all existing methods with a single method called standardized measurement method (Sands et al., 2018), while the core indicator method of Basel II is used in most banks. Medium is still very common, because most of the 14 interviewees believe that the Basel II's proposal to use the basic indicator method has been used by their banks to calculate operational risk buffers. This shows that the regulatory agencies are behind and lack policy enforcement, which has swallowed up the risk management departments of commercial banks operating in Pakistan.

This paper has contributed toward the foundations of literature in the area of operational risk which is still at evolving stage especially in Pakistani and though the intended sector were banks, the research may be extended to other financial institutions too as operational risk in not peculiar to only banks. Moreover, any research work cannot be considered complete without explaining its limitations. Similarly, the current study also encountered limitations at three fronts. Firstly, due to the Corona virus outbreak in Pakistan during the data collection period i:e December 2019 to February 2020,the number of participants were not easy to access and therefore the study took a little longer i:e the study ended in April 2020 instead of February 2020. Secondly, the participants who were already in small numbers pertaining to risk departments and that too willing to participate were further reduced in numbers and got limited thereby leading to a smaller sample size for interviews than had been planned. Additionally, the study includes commercial banks, while other categories such as Islamic banks, specialized banks and microfinance banks are out of reach and was excluded in this study. 
This study broadens the scope of operational risk research by focusing on a specific developing country which lacks pace with the international standards. The followings could be worthy of future research that directly stem from this study i:e future research can be developed in relation to operational risk's development i.e. identification, estimation, evaluation or mitigation or even a similar study as above from the regulator's perspective can be a good yardstick for the banking industry. 


\section{References}

Aathira, K.\& Shanthi, R. (2013). Basel III-The Impact on Banking Sector.Sumedha Journal of Management, 2(2), p.4.

Abdymomunov, Azamat, \&Atanas Mihov. (2017). Operational risk and risk management quality: Evidence from US bank holding companies. Journal of Financial Services Research 1-21.

Aebi, V.Sabato, G. \& Schmid, M.(2012). Risk management, corporate governance, and bank performance in the financial crisis. Journal of Banking and Finance, 36(12), 3213-3226.

Akkizidis, I.\&Kalyvas, L. (2018). Final Basel III Modelling: Implementation, Impact and Implications. Springer.

Al-Tamimi, H. \& Al-Mazrooei, F.M. (2007). Banks' risk management: a comparison study of UAE national and foreign banks. The Journal of Risk Finance, 8(4), pp. 394-409.

Anwer, Y. (2013).Operational risk management in Pakistan - issues and challenges, Bank of International Settlementcentral bankers' speeches, https://www.bis.org/review/r130215b.pdf

Arif, A. \& Anees, A.N. (2012). Liquidity risk and performance of banking system. Journal of Financial Regulation and Compliance, 20(2), pp.182-195.

Attride-Stirling, J. (2001). Thematic networks: an analytic tool for qualitative research. Qualitative research, 1(3), 385-405.

Birindelli, Giuliana, \& Paola, Ferretti. (2017). Operational risk management in banks. Palgrave Macmillan Studies in Banking and Financial Institutions

Boora, K. \& Jangra, K. (2019). Preparedness level of Indian public sector banks for implementation of Basel III. Managerial Finance.

Braun, Virginia,\& Victoria Clarke.(2006). Using thematic analysis in psychology. Qualitative research in psychology 3, no. 2: 77-101.

Chernobai, A. Ozdagli, A. K. \& Wang, J. (2018). Business complexity and risk management: evidence from operational risk events in US bank holding companies. SSRN 2736509.

Cohen, L. Manion, L.\& Morrison, K. (2017). Research methods in education. Routledge. 
Dan, C. Gu, H.\& Xu, K. (2005). The Impact of Hedging on Stock Return and Firm Value.Department of Economics Department of Mathematics and Statistics Dalhousie University

Gillet, R. Georges, H. \& Severine, P. (2010). Operational risk and reputation in the financial industry. Journal of Banking $\mathcal{E}$ Finance 34, no. 1 224-235.

Gurrea-Martínez, A. \& Remolina, N. (2019). The dark side of implementing Basel capital requirements: Theory, evidence, and policy.Journal of International Economic Law, 22(1), 125-152.

Habib, S. Masood, H. Hassan, T. Mubeen, M. \& Baig, U. (2014). Operational risk management in corporate and banking sector of Pakistan. Information and Knowledge Management (Vol. 4, No. 5).

Heidinger, D. \& Gatzert, N.2018. Awareness, determinants and value of reputation risk management: Empirical evidence from the banking and insurance industry.Journal of Banking \& Finance, 91, 106-118.

Hemrit, W.\& Arab, M. B. (2012). The major sources of operational risk and the potential benefits of its management. Journal of Operational Risk, 7(4), 71-92.

Hopkin, P.(2018). Fundamentals of risk management: understanding, evaluating and implementing effective risk management. Kogan Page Publishers.

Hudin, N. S.\& Hamid, A. B. A. (2014). Drivers to the implementation of risk management practices: a conceptual framework. Journal of Advanced Management Science Vol, 2(3), 163-169.

Jiang, X. (2018). Operational risk and its impact on North American and British banks. Applied Economics 50, no. 8 (2018): 920-933.

King, N. (2004). Using templates in the thematic analysis of texts. In C. Cassell\& G. Symon (Eds.), Essential guide to qualitative methods in organizational research (pp. 256-270). London: Sage

King, P.\&Tarbert, H. (2011). Basel III: An Overview. Banking \& Financial Services Policy Report, 30(5), 1-18.

Kozarević, Emira, SenijaNuhanović, \& Mirnesa, Baraković Nurikić. (2013). Comparative analysis of risk management in Conventional and Islamic Banks: the case of Bosnia and Herzegovina."International Business Research 6, no. 5 180193.

Leone, Paola,\& Pasqualina, Porretta, (2018). Operational risk management: Regulatory framework and operational impact." In Measuring and Managing Operational Risk, pp. 25-93. Palgrave Macmillan, Cham 
Lessambo, F. I. (2020). Banks' Capital Adequacy. In The US Banking System (pp. 185207). Palgrave Macmillan, Cham.

Marshal, M. N. (1996) Sampling for qualitative research. Family practice, 13(6), 522526

Masood, Omar, \& John, Fry (2012). Risk management and Basel-Accordimplementation in Pakistan. Journal of financial regulation and compliance 20, no. 3 : 293-306

Muljawan, D. Dar, H. A.\& Hall, M. J. (2004). A capital adequacy framework for Islamic banks: the need to reconcile depositors' risk aversion with managers' risk taking.Applied Financial Economics, 14(6), 429-441.

Nowell, L. S.Norris, J. M.White, D. E.\& Moules, N. J. (2017). Thematic analysis: Striving to meet the trustworthiness criteria. International journal of qualitative methods, 16(1), 1609406917733847.

Pakhchanyan, S. (2016). Operational Risk Management in Financial Institutions: A Literature Review. International Journal of Financial Studies, 4(4), p.20

Rehman, A. A. Benamraoui, A. \& Dad, A. M. (2018). A comparative study of Islamic and conventional banks' risk management practices: empirical evidence from Pakistan. Journal of Banking Regulation, 19(3), 222-235.

Sands, P.Liao, G. \& Ma, Y. (2018). Rethinking operational risk capital requirements. Journal of Financial Regulation, 4(1), 1-34.

Sharifi, S. Haldar, A.\& Rao, S. N. (2016). Relationship between operational risk management, size, and ownership of Indian banks. Managerial Finance.

Slovik, P. (2012). Systemically important banks and capital regulation challenges. OECD Economics Department Working Papers 916, OECD Publishing.

Warren, C. A. B. (2002). 'Qualitative Interviewing', in J. F. Gubrium \& J. A. Holstein (eds), Handbook of Interview Research: Context and Method. Thousand Oaks, CA: Sage.

Wei, R.Cummins, J.Lewis, C.(2006). The Market Value Impact of Operational, Journal of Banking \& Finance, 2006, vol. 30, issue 10, 2605-2634

$\mathrm{Xu}$, Y.Pinedo, M. \& Xue, M.2017. Operational risk in financial services: A review and new research opportunities. Production and Operations Management, 26(3), pp.426445 . 
Zeuli, M.\& Carvalhal, A. (2018). Back testing Basel III: evaluating the market risk of past crises through the current regulation. Applied Economics, 50(59), 6382-6396.

Zins, A. \& Weill, L. (2017). Islamic banking and risk: The impact of Basel II. Economic Modelling, 64, 626-637. 